\title{
IDENTIFICATION OF CRITICAL FACTORS AFFECTING THE STUDENTS' ACCEPTANCE OF LEARning MANAgEMENT System (LMS) IN SAUdi Arabia
}

\author{
IDENTIFICAÇÃO DE FATORES CRÍTICOS QUE AFETAM A ACEITAÇÃO DO SISTEMA DE GERENCIAMENTO \\ DE APRENDIZAGEM (LMS) DOS ALUNOS NA ARÁBIA SAUDITA
} IDENTIFICACIÓN DE FACTORES CRÍTICOS QUE AFECTAN LA ACEPTACIÓN DEL SISTEMA DE GESTIÓN
DEL APRENDIZAJE (LMS) POR PARTE DE LOS ESTUDIANTES EN ARABIA SAUDITA

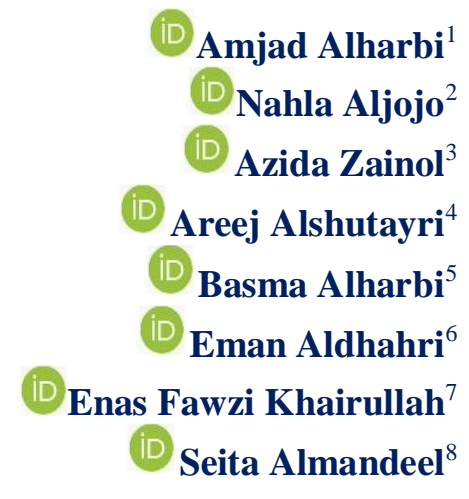

Cite as - American Psychological Association (APA)

Alharbi, A., Aljojo, N., Zainol, A., Alshutayri, A., Alharbi, B., Aldhahri, E., Khairullah, E. F., \& Almandeel, S. (2021, May/Aug.). Identification of critical factors affecting the students' acceptance of Learning Management System (LMS) in Saudi Arabia. International Journal of Innovation - IJI, São Paulo, 9(2), 353-388. https://doi.org/10.5585/iji.v9i2.19652.
Abstract
Objective of the study: The objective is to identify factors that influence student's acceptance of Learning Management System (LMS) using the Unified Theory of Acceptance and Use of Technology (UTAUT) model. This study investigates how UTAUT factors affect students' intention and attitudes to use Blackboard as a LMS at King Abdulaziz University in Saudi Arabia.
Methodology/approach: This study proposes a research model based on UTAUT factors 'Effort Expectancy (EE), Performance Expectancy (PE), Perceived Functionality (PF), Facilitating Condition (FC), Social Influence (SI)', Behavioural Intention to use (BI) and Usage Behaviour. The survey research methodology was adopted using questionnaire to identifying factors that influencing the students' intention and attitudes towards LMS.
Originality/relevance: The study relates corporate LMS to support educational institutions to enhance the students' acceptance and attitudes to use in Saudi Arabia.

\footnotetext{
1 Graduate Student. Information System Department, Faculty of Computing and Information Technology, Kind Abdulaziz University -KAU. Jeddah, Saudi Arabia. aalharbi1481@ stu.kau.edu.sa

2 Associate Professor. Information system and Technology Department, College of Computer Science and Engineering, University of Jeddah - UJ. Jeddah, Saudi Arabia. nmaljojo@ uj.edu.sa

3 Assistant Professor. Software Engineering Department, College of Computer Science and Engineering, University of Jeddah - UJ. Jeddah, Saudi Arabia. azzainol@uj.edu.sa

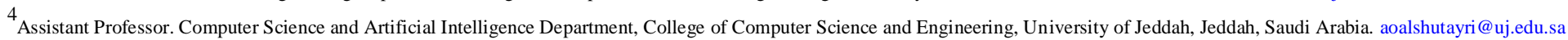

5 Assistant Professor. Computer Science and Artificial Intelligence Department, College of Computer Science and Engineering, University of Jeddah, Jeddah, Saudi Arabia. bmalharbi@uj.edu

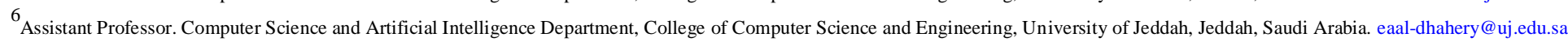

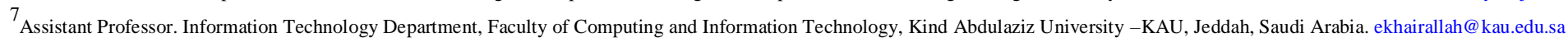

${ }^{8}$ Associate Professor. Faculty of Economics \& Administration, Department of Business Administration, King Abdulaziz University - KAU, Jeddah, Saudi Arabia. sialmandeel@kau.edu.sa
} 
Main result: The results indicate that $\mathrm{PE}, \mathrm{PF}, \mathrm{FC}$ and SI factors were significant and directly influence on students' BI Blackboard. Both PE and FC are second factors that affect students' intention and EE factor does not impact the student's BI.

Theoretical/methodological contributions: The study contributes to the body of knowledge in developing the research model using UTAUT model by showing the factors affecting the students' intention in using LMS and usage behavior in Saudi Arabia.

Social/management contributions: This study contributes in understanding the critical factors affecting the Saudi Arabia students' intentions in using Blackboard. Another study should be extended to other universities by using different methods to test the model and incorporate different moderating factors to accept and use the Blackboard.

Keywords: Learning Management System. Unified theory of acceptance and use of technology. Behavioural intention to use. Regression analysis.

\section{Resumo}

Objetivo do estudo: O objetivo é identificar os fatores que influenciam a aceitação do aluno do Sistema de Gestão de Aprendizagem (LMS) usando o modelo da Teoria Unificada de Aceitação e Uso da Tecnologia (UTAUT). Este estudo investiga como os fatores UTAUT afetam a intenção e as atitudes dos alunos para usar o Blackboard como um LMS na King Abdulaziz University, na Arábia Saudita.

Metodologia / abordagem: Este estudo propõe um modelo de pesquisa baseado nos fatores UTAUT 'Expectativa de Esforço (EE), Expectativa de Desempenho (PE), Funcionalidade Percebida (FP), Condição Facilitadora (FC), Influência Social (SI)', Intenção Comportamental usar (BI) e comportamento de uso. A metodologia de pesquisa da pesquisa foi adotada por meio de questionário para identificar os fatores que influenciam a intenção e as atitudes dos alunos em relação ao LMS.

Originalidade / relevância: O estudo relaciona o LMS corporativo para apoiar instituições educacionais a fim de aumentar a aceitação e as atitudes dos alunos para uso na Arábia Saudita.

Resultado principal: Os resultados indicam que os fatores PE, PF, FC e SI foram significativos e influenciam diretamente no quadro negro de BI dos alunos. Ambos PE e FC são segundos fatores que afetam a atenção dos alunos e o fator de EE não afeta o BI do aluno.

Contribuições teóricas / metodológicas: $\mathrm{O}$ estudo contribui para o corpo de conhecimento no desenvolvimento do modelo de pesquisa usando o modelo UTAUT, mostrando os fatores que afetam a intenção dos alunos em usar LMS e o comportamento de uso na Arábia Saudita.

Contribuições sociais / de gestão: Este estudo contribui para a compreensão dos fatores críticos que afetam as intenções dos alunos da Arábia Saudita ao usar o Blackboard. Outro estudo deve ser estendido a outras universidades, usando diferentes métodos para testar o modelo e incorporar diferentes fatores moderadores para aceitar e usar o Blackboard.

Palavras-chave: Sistema de Gestão da Aprendizagem. Teoria unificada de aceitação e uso de tecnologia. Intenção comportamental de uso. Análise de regressão.

\section{Resumen}

Objetivo del estudio: El objetivo es identificar los factores que influyen en la aceptación por parte del estudiante del Sistema de Gestión del Aprendizaje (LMS) utilizando el modelo de Teoría Unificada de Aceptación y Uso de la Tecnología (UTAUT). Este estudio investiga cómo los factores UTAUT afectan la intención y las actitudes de los estudiantes para usar Blackboard como LMS en la Universidad King Abdulaziz en Arabia Saudita.

Metodología / enfoque: Este estudio propone un modelo de investigación basado en los factores UTAUT 'Expectativa de esfuerzo (EE), Expectativa de rendimiento (PE), Funcionalidad percibida (FP), Condición facilitadora (FC), Influencia social (SI)', Intención conductual para usar (BI) y Usage Behavior. La metodología de investigación de la encuesta se adoptó utilizando un cuestionario para identificar los factores que influyen en la intención y las actitudes de los estudiantes hacia el LMS.

Originalidad / relevancia: El estudio relaciona los LMS corporativos con el fin de ayudar a las instituciones educativas a mejorar la aceptación y las actitudes de los estudiantes para su uso en Arabia Saudita. 
Resultado principal: Los resultados indican que los factores PE, PF, FC y SI fueron significativos y tuvieron una influencia directa en el BI Blackboard de los estudiantes. Tanto la educación física como la FC son segundos factores que afectan la atención de los estudiantes y el factor EE no afecta el BI del estudiante.

Contribuciones teóricas / metodológicas: El estudio contribuye al cuerpo de conocimiento en el desarrollo del modelo de investigación utilizando el modelo UTAUT al mostrar los factores que afectan la intención de los estudiantes en el uso de LMS y el comportamiento de uso en Arabia Saudita.

Contribuciones sociales / de gestión: Este estudio contribuye a comprender los factores críticos que afectan las intenciones de los estudiantes de Arabia Saudita al utilizar Blackboard. Otro estudio debería extenderse a otras universidades utilizando diferentes métodos para probar el modelo e incorporar diferentes factores moderadores para aceptar y utilizar Blackboard.

Palabras clave: Sistema de Gestión del Aprendizaje. Teoría unificada de aceptación y uso de la tecnología. Intención de uso conductual. Análisis de regresión.

\section{Introduction}

Today, the world has been witnessing a great dramatic change because of the introduction of computers in everyday life. This has led to several developments in different fields including education. A wide range of e-learning systems have been improved because of the use of Internet and technologies. This trend has changed the learning and teaching activities for better within the higher educational institutions Alkhattabi, et al. (2011). Information and Communication Technology (ICT) has also improved the quality of education (Byungura, 2015).

The learning management system (LMS) is one of the ICT tools that is used in the educational field. LMS is a technology that has emerged rapidly and is used widely in higher education, specifically in both open-source such as Moodle or commercial LMS such as Blackboard (Al-Busaidi \& Al-Shihi, 2010). Paulsen argued that the availability of LMS is regarded as a significant factor that leads to e-learning success (Paulsen, 2003). LMS is also called a learning platform which refers to a wide range of systems that assist students and teachers to access online learning services (Paulsen, 2002). LMS provides services that differ from one system to another. Nevertheless, there are common services which are available in LMS that include 'performance management, assessments, access control, study schedule documentation, provision of learning content, and communication facilities' (Alharbi \& Drew, 2014). LMS is one of the approaches of e-learning or online learning (Ülker \& Y1lmaz,2016), which involve the organization and management of e-learning activities within a system, such as assignments, syllabus, messages, student enrolment, exams, lesson plans and so on (Almaiah, et al., 2020). The LMS has been described to be sustainable, affordable and efficient especially, providing a great alternative to face-to-face classes through free virtual classes when school 
activities have to cease in the case of a state of emergency, such as the one of COVID-19 pandemic emergency (Juárez Santiago, et al., 2020).

Online learning has been used across the world within higher education institutions because of the benefits it offers. These benefits include 'improving access to training and education, improving the quality of learning and teaching, facilitating collaborative learning and information exchange, responding to innovation technology, realizing flexibility for place and time, and preparation for lifelong learning with low costs' (Liu, et al., 2005; Shen, et al., 2006; Saadé \& Kira, 2006; Farahat, 2012). E-learning is receiving a tremendous implementation and use by educational institutions either in a blended learning or as a complete e-learning environment. Notably, the recent COVID-19 pandemic has forced many educational institutions in the world to adopt online learning and distance learning, causing a revival of the need to explore online teaching and learning opportunities (Almaiah, et al., 2020).

On the other hand, there are some disadvantages of e-learning in the educational field. Bouhnik and Marcus stated that there are common expressions of dissatisfaction because of the absence of direct interaction not only among the students themselves but also between the students and instructors. This is also caused by the absence of a learning atmosphere. The researchers also mentioned that some students complained about their questions not being answered sufficiently, while others complained that they were not provided enough time to learn new information. Moreover, there are other factors that lead to students' dissatisfaction. These factors are personal and environmental such as 'the low of self-motivation, the complexity of understanding new topics without the instructor's instruction, and the absence of self-efficacy' in the e-learning use (Bouhnik \& Marcus, 2006; Dutton, et al., 2001).

It is noteworthy that some institutes in the educational field have implemented elearning systems in their programs. In spite of this, the benefits of these systems are related to the failure or success of using such systems (Pituch \& Lee, 2006). Similar to any other information systems, users' acceptance and usage are significant measures of the system's success (Saade, et al., 2007). Thus, students' acceptance should be taken into consideration, otherwise the information systems tend to fail.

Several universities that use e-learning face various difficulties regarding the adoption of successful strategies which include the effectiveness and acceptance of delivering and teaching courses. More significantly, realizing students' acceptance of online learning is regarded as the most important stage aimed to develop and implement a successful e-learning 
environment (Žuvić-Butorac, et al., 2011). Additionally, investigating students’ intentions and the other factors that influence students' beliefs about e-learning can support the educational management to develop effective ways for attracting numerous students who prefer to be involved in e-learning systems (Al-Adwan, et al., 2013). Thus, it is important to investigate the factors which reveal 'students' acceptance, intention and attitude' to use e-learning systems.

A lot of models were presented to investigate the factors which identify the user's intention to accept and use e-learning systems such as 'The Technology Acceptance Model (TAM), the Theory of Planned Behaviour (TPB), Innovation Diffusion Theory (IDT), Delone and Mclean (D\&M) information system success model and the Unified Theory of Acceptance and Use Technology (UTAUT)'. TAM is the most common model that is adopted worldwide. Therefore, it is the foundation of the following modified models proposed by several researchers (Tarhini, et al., 2015).

In the Saudi context, the Ministry of Higher Education has recognised the importance of ICT in different universities all around Saudi Arabia. Consequently, the ministry accepted elearning as an element of the national plan which aims to adopt distance learning, e-learning, and blended learning in higher education. This led to the establishment of the Saudi Electronic University in 2011. Furthermore, several universities in the kingdom established the deanship of e-learning and employed staff to help with blended learning and LMS adoption in the courses (Bousbahi \& Alrazgan, 2015). A study was conducted among 160 Diploma students from the Department of Information Systems at the King Khalid University in Saudi Arabia using TAM. This study has indicated that students were qualified to use the E-Learning System and the perceived ease of use and perceived usefulness were directly affect the student's attitudes toward using the E-Learning System. (Vasanthi Muniasamy, et al., 2014).

In this study, the objective is to identify the different factors that can influence student's acceptance of Blackboard by using the Unified Theory of Acceptance and Use of Technology (UTAUT) model that involves independent variables such as 'Effort Expectancy (EE), Performance Expectancy (PE), Perceived Functionality (PF), Facilitating Condition (FC), Social Influence (SI)' and dependent variables including Behavioural Intention to use (BI) and Usage Behaviour. Furthermore, the study aim to investigate how UTAUT factors can adapt students' intention and attitudes to use Blackboard at King Abdulaziz University in Saudi Arabia. Hence, this study formulated a research question to respond to these issues: 
- What are the critical factors that influence students' acceptance of using Blackboard through using the UTAUT model at King Abdulaziz University?

The subsequent sections of this paper are structured as follows; section 2 discusses the related literature works. Section 3 elaborates the proposed research model and hypotheses. Section 4 presents the research methodology. Section 5 presents the analysis and presentation of results. Discussion on the results is presented in section 6. Finally, section 7 outlines the conclusion and future works.

\section{Reviews}

This section addresses the acceptance of technology which has been influenced by a significant increase in the amount of research. This study reviews on exploring the acceptance of technology in the educational field. Technology acceptance is 'a user's willingness to employ technology for the tasks it is designed to support' (Bousbahi \& Alrazgan, 2015). There have been a number of case studies aimed to identify, explore, and explain the factors that have students' acceptance of technology to more acceptance and effective utilization.

This section of related works has been divided into the following subsections: TAM and UTAUT in international and Saudi Arabia studies in order to demonstrate the gap that exist in acceptance of LMS. TAM and UTAUT models were found mostly investigated and the UTAUT model was recommended to measure students' intention to continued use of e-learning system (Rahman, et al., 2020).

\subsection{TAM in International and Saudi Arabia Studies}

A study by Estriegana et al. (2019) evaluated students' acceptance of technology as well as and how an online learning environment is adopted. This study followed the TAM and examined other factors including perceived efficiency, satisfaction, and playfulness. Their findings showed that extending TAM can result in a theoretical model that can aid in better understanding the acceptance of an online learning environment by users including practical work as well as virtual laboratory. They also noted that playfulness, efficiency, along with students' extent of satisfaction have a positive impact on the original TAM variables as well as on this technology's acceptance by students (Estriegana et al., 2019).

Tarhini et al. (2015) conducted a study to apply the TAM factors which are perceived usefulness, perceived ease of use, and attitude towards usage of the system to investigate the 
students' acceptance of Rich Site Summaries (RSS) feeds on the Blackboard system in a university in Lebanon. A questionnaire was distributed among 235 students. Researchers applied a structural equation modelling method to investigate the factors concerning their relationships between each other within the research model. The results showed that the perceived usefulness and attitude towards usage of the RSS are important factors which have an influence on the behavioural intention of the students, thus making them use the system, while perceived ease of use had no effect compared to perceived usefulness and attitude which were critical factors towards the use of this system (Tarhini, et al., 2015).

Another study by Al-Adwan et al. (2013) examined the factors which affect e-learning by investigating students' acceptance and intention to use e-learning within the universities in Jordan. They used a questionnaire to explore the degree of acceptance of e-learning among students and to determine the elements that affect the successful use of e-learning which depends on the original TAM. The findings showed that, in order to expect and understand the intentions of the users regarding using e-learning, TAM can be used as a theoretical base. It was demonstrated that perceived ease of use affected attitude and perceived usefulness while perceived usefulness did not have a significant effect on the students' attitudes (Al-Adwan, et al., 2013).

Juhary (2014) investigated the students' perceptions of using the LMS at the Defence University of Malaysia based on the original TAM. The results showed that the students' perceived usefulness and ease of use affected students' attitudes concerning the LMS. Furthermore, students' attitudes affected their intention to use LMS. Therefore, students experiencing positive perceived usefulness and ease of use also had positive attitudes towards the use of LMS. As a result, those students had behavioural intentions for using LMS. In this paper, there were attitudes that were considered positive towards using LMS. Nevertheless, there were some technical issues that had to be dealt with to ensure that the LMS was able to function effectively (Juhary, 2014).

Mabed and Koehler's (2012) study combined self-efficacy and system quality as an extension to the TAM in their proposed model to explore the effective elements that influence students' acceptance of using the Open Learning and Training (OLAT) system at a school in Egypt. The questionnaire was used before in the studies that were done in which 27 items were chosen to address all the factors that existed in the research model. The findings revealed that perceived ease of use is the major variable that links other variables with attitude, perceived usefulness, and system usage. Moreover, the findings assist the existence of an impact of system 
quality that is powerful and positive on perceived usefulness, perceived ease of use, and selfefficacy while self-efficacy increase perceived usefulness, and perceived ease of use but did not affect the attitude that led to the use of OLAT (Mabed \& Koehler, 2012).

Yeou (2016) conducted a study at the Moroccan University to examine students' attitudes towards the use of Moodle. This study focused on computer self-efficacy as an external factor and its relationship with another construct of TAM. The survey was distributed among 47 students, and structural equation modelling was used to analyse students' acceptance of the system. The findings confirmed the importance of computer self-efficacy in directly influencing perceived usefulness, perceived ease of use, and attitude concerning using Moodle. Additionally, it had an indirect positive effect on the intention to use Moodle. Computer selfefficacy is also considered a very important motivational factor (Yeou, 2016).

Moreno et al. (2017) explored the individual differences, system characteristics, facilitating conditions, and social factors to demonstrate students' intention and attitude towards using e-learning. Their results concluded that both students' perceptions of system usefulness and ease of use affected their intention positively in order to allow them to use e-learning systems effectively. The findings also showed that the students' attitudes towards the LMS fully mediate these effects. Moreover, students' cognitive and self-efficacy affect both system usefulness and ease of use. Further, they were affected by system interactivity and facilitating conditions (Moreno, et al., 2017).

Furthermore, Revythi and Tselios (2017) assessed both the technology acceptance and behavioural intention for using the LMS which is based on the TAM. The researchers focused on eight variables which are self-efficacy, year, perceived usefulness, perceived ease of use, system access, social norm, and behavioural intention to use in order to investigate how students accept or do not accept the systems of educational learning as well as the influences of such factors on the technology acceptance. This study selected 345 students from Patras University. The findings revealed that system access, social norm, and self-efficacy influence behavioural intention to use LMS effectively (Revythi \& Tselios, 2017).

Tarhini et al. (2017) developed a model based on the TAM to explore the influences of the culture of individual-level on the acceptance of the tools of e-learning by some students in Lebanon. To avoid the TAM's application limitations in developing countries, the authors tried to expand the TAM by including two constructs which included quality of work life and subjective norms as well as certain cultural variables as moderators. These cultural variables were attained from various dimensions such as individualism/collectivism, 
masculinity/femininity, power distance, and uncertainty avoidance which were examined at the personal level so that they could be incorporated in the expanded TAM as types of moderators. The required data were taken from 569 students in Lebanon who used the tools of e-learning through a survey as an instrument for collecting data. That data was analysed by using the technique of structural equation modelling and multi-group analysis. The results showed that perceived ease of use, perceived usefulness, subjective norms, and quality of work life are the major determinants of students' behavioural intention concerning e-learning. The results also showed that subjective norms' relationship with behavioural intention was very sensitive to the different features in the values of a person's culture and the major moderating effects that were noticed for the four cultural dimensions being studied. There were certain moderating effects of culture that were discovered through perceived usefulness and perceived ease of use as well. However, quality of work life had not impact that could be moderated by masculinity/femininity, as the other studies had expected (Tarhini et al., 2017).

Moreover, Farahat (2012) conducted a study at the Egyptian Universities to establish and define the determinants of students' acceptance of e-learning. He also intended to examine to the extent to which these determinants can form students' intention to use e-learning. The researcher modified conceptual framework based on the TAM that included social influence of the students' referent group. This referent group included instructors, peers, and family members. There are other constructs such as perceived ease of use, perceived usefulness, and attitude towards e-learning that affect students' behavioural intention to use the online system. A questionnaire was distributed among 153 students who were under-graduates and used elearning. The findings revealed that perceived usefulness, perceived ease of use, and attitudes were important determinants of students' intention to use and practice e-learning. The probability of using all the social factors of students' referent group, perceived usefulness, perceived ease of use, and their attitudes towards e-learning in terms of their behavioural intention to use e-learning was approved(Farahat, 2012).

Claar et al. (2014) examined the impact of different demographic factors such as education levels, age, race, and gender on students' acceptance of the LMS. The researchers first reviewed the literature to identify the essential increases in online learning in the country, selection criteria for the new LMS in university, reasons for the university to change the LMS system, and research on TAM and UTAUT theories of technology acceptance. Then, a questionnaire was distributed among students which aimed to measure different technology acceptance factors and to utilize the TAM. The findings confirmed the following relationships 
between variables: perceived ease of use (PE) has a major positive impact on perceived usefulness (PU); perceived usefulness has a major positive impact on the attitude towards using (AT); perceived ease of use (PE) has a major positive impact on the attitude towards using (AT); perceived usefulness (PU) has a major positive impact on behavioural intentions to use (BI); attitude towards using has a major positive impact on behavioural intentions to use; higher educational level leads to a greater possibility of the new LMS to be accepted; and the person's age being higher leads to the person more likely to perceive LMS more negatively. However, race and gender did not affect any of the TAM variables (Claar, et al., 2014).

\subsection{UTAUT in International and Saudi Arabia Studies}

Dečman (2015) examined the suitability of UTAUT within a particular e-learning environment that is mandatory in higher education for assessing the way in which gender as well as students' previous education impacts the use and acceptance of this technology. The empirical research follows the theoretical background and involves a data collection method that includes a survey, structural equation modelling, and a data validation method that involves factor analysis. According to the findings, the UTAUT model has overall applicability in elearning settings and performance expectancy along with has considerably impact on the intention to use the technology. Moreover, the results prove that gender or students' previous education do not impact the model fit significantly (Dečman, 2015).

Sattari et al. (2018) examined the factors influencing the acceptance of Web-Based Training (WBT) by students based on the UTAUT theory. The study collected data from students at Tabriz University through survey. According to the findings, WBT acceptance is directly influenced by performance expectancy, effort expectancy, facilitating condition but social influence not affected the student's behavioural intention. Further, UTAUT explains 58\% of the variance for adopting WBT (Sattari, et al., 2018).

Fianu et al. (2018) examined the factors impacting the adoption and use of Massive Open Online Courses (MOOC) by students in particular Ghanaian universities. They established a research model using the UTAUT and conducted a survey for collecting data from MOOC-assigned students. The study's results showed that the intention to use MOOC was affected by computer self-efficacy, system quality, and performance expectancy. They further observed that MOOC usage is influenced by facilitating conditions, instructional quality, and MOOC usage intention. Moreover, the results that social influence and effort expectancy did not influence MOOC's usage intention significantly (Fianu, et al., 2018). 
A study conducted by Buabeng-Andoh and Baah (2019) investigated university students' actual use of LMS using UTAUT and used quantitative and qualitative research strategies. The quantitative analysis revealed that performance expectancy, effort expectancy and institutional support influenced students' actual use of LMS whereas social influence and infrastructure support did not influence students' actual use. However, the results from qualitative analysis found lack of training, unavailability of internet connection and poor electricity supply as major concerns that affect students' actual usage of LMS (Buabeng-Andoh \& Baah 2019).

An extended UTAUT model with the addition of perceived enjoyment, mobile selfefficacy, satisfaction, trust, and perceived risk moderators, was proposed by Chao (2019) to predict the factors affecting students' behavioral intentions toward using mobile learning. The study showed that the behavioral intention was significantly and positively influenced by satisfaction, trust, performance expectancy, and effort expectancy. Also, perceived enjoyment, performance expectancy, and effort expectancy had positive associations with behavioral intention. Also, mobile self-efficacy had a significantly positive effect on perceived enjoyment; and perceived risk had a significantly negative moderating effect on the relationship between performance expectancy and behavioral intention (Chao, 2019).

In a study by Rutter and Smith (2019) investigated the use and acceptance of the use of Blackboard using the UTAUT model with extension of Technical Support (TS) factor. The study revealed that TS is fundamental in understanding the use and acceptance of e-learning systems, such as Blackboard LMS (Alshehri, et al., 2019).

From these reviews, it can be concluded that TAM and UTAUT models were frequently investigated in international and Saudi Arabia studies with UTAUT model was recommended to measure students' intention to continue use of e-learning system. Although these models are frequently used in measuring the students' acceptance, the research gap among in identifying the accurate factors that influencing the students' acceptance is still exist. In the previous studies, there were various different determinants with extended UTAUT have shown in understanding the use and acceptance of e-learning in education domain. Hence, this support our study that facilitate the UTAUT to measure the students' intention to use blackboard in King Abdulaziz University. 


\section{Research model and hypotheses}

This section describes the research model and hypotheses for this study for measuring the students' acceptance in using Blackboard.

\subsection{Research model}

The present study proposes a conceptual model, which is based on the Unified Theory of Acceptance and Use of Technology (UTAUT) model. This model includes five independent variables; Performance Expectancy (PE), Effort Expectancy (EE), Social Influence (SI), Perceived Functionality (PF), and Facilitating Conditions (FC), to investigate different students' perceptions. It also includes two dependent variables, the students' behavioural intention and LMS acceptance that can be determined by testing the following hypotheses, altogether formed seven constructs, as illustrated in Figure 1. However, following the numerous statistical analysis techniques as well as SEM analysis techniques, the theoretical model is tested and re-structured so that it can more reliably and accurately fit the sampled data. Further, the fitting process leads to a final model that includes six constructs, including PE, PF, SI, BI, UB, and FC.

\section{Figure 1}

\section{Proposed research model}

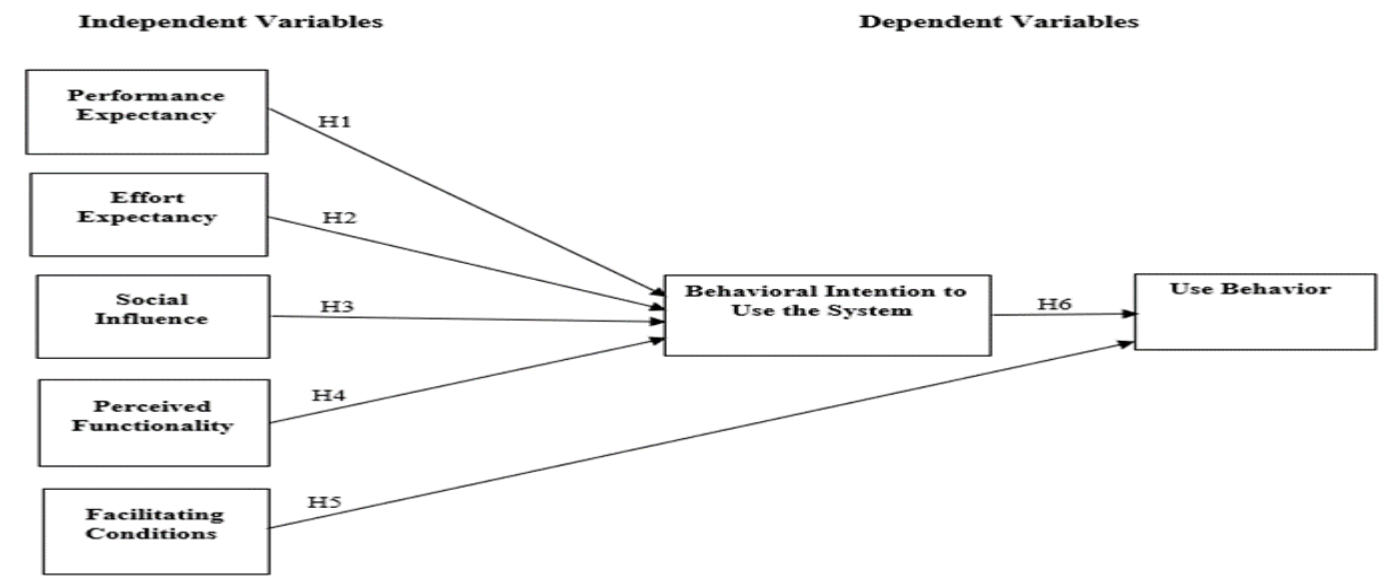

Source: Research model. 


\subsection{Research hypotheses}

The research hypotheses were stated to investigate the five independent variables of the proposed model.

Performance Expectancy: In the information system field, the user's performance expectancy refers to the degree to which a person believes that using the information system will benefit his/her job performance (Venkatesh, et al., 2003). In this research, we hypothesized that using Blackboard will positively affect the behavioural intention of students in King Abdulaziz University.

H1: Performance expectancy will positively affect students' behavioural intention to use Blackboard.

Effort Expectancy: The second construct is the effort expectancy which concerns the level of ease related to the use of a specific information system (Venkatesh, et al., 2003). Therefore, we hypothesized that the students' effort expectancy from Blackboard will influence their behavioural intention towards this system.

H2: Effort expectancy will positively influence students' behavioural intention towards Blackboard.

Social Influence: The third independent construct is social influence which is the degree to which a person perceives other important people's belief that he/she must use the system (Venkatesh, et al., 2003). Thus, we hypothesized that the social environment of Saudi Arabia will influence students' behavioural intention.

H3: A high level of social influence will positively influence the students' behavioural intention.

Perceived Functionality: The fourth independent construct is perceived functionality which refers to the perceived ability of the system and the activities that students undertake with the LMS such as 'accessing course contents, communication, and selfassessment' (Swesi, 2012). Thus, we hypothesized that the perceived functionality of the Blackboard will influence students' behavioural intention.

H4: A high level of perceived functionality will positively influence the students' behavioural intention.

Facilitating Conditions: The last independent construct is Facilitating Conditions which, according to the UTAUT model, is the degree to which an individual believes that both organizational and technical infrastructure exist to assist the use of the 
information system (Venkatesh, et al., 2003). Therefore, it is important to hypothesize that the university institutional structures, rules, policies, and technical infrastructures will impact the acceptance and use of the Blackboard.

H5: A high perceived level of Blackboard Facilitating Conditions will influence the level of acceptance and use of the Blackboard positively.

\section{Methodology}

This section describes the methodology for identifying critical factors that affecting the students' acceptance of using blackboard.

\subsection{The questionnaire design}

In this study, the questionnaire was developed by evaluating numerous related previous studies. Moreover, the measurement items were obtained from scholars such as Venkatesh et al. (2003) (Venkatesh et al., 2003), Bhrommalee (2011) (Bhrommalee, 2011), Swesi (2012) (Swesi, 2012), Pituch (2006) (Pituch, 2006), and Byungura (2015) (Byungura, 2015). The research questionnaire includes 29 items for measuring the unobserved latent variables concerning the theoretical model of the study. Although these questionnaire items were based on previous studies which validated them, certain modifications were made to the items taking into account the concerned research system which is the Blackboard at King Abdulaziz University. Moreover, the questionnaire includes a cover page that details the study as well as two major parts, of which the first part refers to the overall demographic information concerning the participants so that a general profile can be developed of the sample population, while the second part involves the measuring items concerning the individual constructs of the theoretical model that provides the data required to assess the research hypothesis. This part refers to an altered version of Venkatesh et al.'s (2003) survey instrument. There are three to six items in this survey instrument that concern all the technology acceptance areas. Further, the items structured so that the questions hat measured every construct area were grouped together, which are performance expectancy, social influence, effort expectancy, facilitating conditions, perceived functionality, use behaviour, and behavioural intention. Following the study's context, the term 'the system' that was used in the original version was replaced by the term 'blackboard', and the statements' structure was maintained. 


\subsubsection{UTAUT constructs}

The questionnaire includes seven factors that explore the student's perspectives relating to the Blackboard based on the UTAUT. Two of them are defined as endogenous factors (dependent variables) (Behavioural Intention and Use Behaviour). Moreover, five factors are identified as exogenous factors (independent variables) and considered to be the basic UTAUT constructs with a new factor of Perceived Functionality used to extent the model: performance expectancy, effort expectancy, social influence, perceived functionality, facilitating conditions, behavioural intention, and use behaviour. The research instrument uses a five-point Likert scale to measure the factors, with five indicating strongly agree and one strongly disagree.

\subsection{Questionnaire distribution, collection and response rate}

The study was conducted from December 2018 to January 2019. The population of the study included undergraduate and graduate students from King Abdulaziz University's different colleges and departments. The students were sent an email using through the Research Services Unit, Deanship of Graduate Studies with a link to the web-survey. It took approximately 15 minutes on average to complete the questionnaire. For ensuring the participants' complete awareness as well as enhancing the response rate, a confidentiality statement was included on the questionnaire's cover page which outlined the study's objective, the responsibility of the researcher regarding the data being gathered, and the right of the participant to withdraw the data they will submit whenever they want. The survey was also provided in Arabic so that there were no language barriers. Moreover, the participants were requested to take part and complete the questionnaire according to how they view the Blackboard used in the education process at King Abdulaziz University. The researcher received 260 responses. The data was then entered in an Excel spreadsheet to be uploaded later into statistical software, after which data entry was accurately verified. The Statistical Package for the Social Science (SPSS) and AMOS software were used to analyse the data. The following chapter will analyse the research questions, examine hypotheses testing, and validate the research model as well as the necessary techniques.

\subsection{Quantitative data analysis techniques}

The Structural Equation Modelling (SEM) is a widely used statistical method concerning behavioural science. The SEM approach can help combine data with theory (Alia, 
2017). For the present study, the SEM method was used for evaluating the gathered data. Various models are included in this method for defining the relationships of the observed variables, understanding the way in which a group of variables are able to determine constructs, as well as the relationships between these constructs (Schumacker \& Lomax, 2004). There are numerous reasons for selecting SEM. This method allows researchers to evaluate and assess the constructs' relationships. It can help examine and rectify any measurement errors, and if ignored can result in a bias being created when estimating parameters (Stage, 1988). This method also uses various measurements to help represent constructs. Further, the variables in SEM are classified into latent variables and observed variables. The latent variables, also called factors, unobserved variables, or constructs, cannot be directly measured and need to be determined based on the measured variables. The latent variables in this study included seven factors: PE, EE, SI, PF, FC, BI, and UB. However, the observed variables refer to a set of variables, which are called measured variables, that can help determine the latent variables. The present study's observed variables included the questionnaire items which measured the seven latent variables.

Latent variables can be further divided into endogenous variables or exogenous variables. While the endogenous variables concern the dependent latent variables such as Behavioural Intention to Use and Use Behaviour that are included in the model and impacted by other variables, the exogenous variables concern the independent latent variables such as performance expectancy, social influence, effort expectancy, facilitating conditions, and perceived functionality that not included in the theoretical based model and are not affected by the model's other variables.

\subsection{Factor analysis}

This study also conducted factor analysis which is a multivariate statistical method that helps decrease the numerous correlated variables to fewer latent dimensions. Factor analysis primarily helps attain parsimony as it uses the least explanatory concepts (variables) for clarifying the most common variance within a correlation matrix. Moreover, factor analysis helps evaluate the measurement scales' validity and reliability (Carmines \& Zeller, 1979). Confirmatory Factor Analysis (CFA) is a significant type of factor analysis that is typically used in the more advanced stages of research analysis where latent variables are tested in terms of the hypothesis [41]. The CFA can provide a final study model derived from the previous 
theoretical model. This final model puts forth the most dependable observed variables that add to the latent variables' strong relationship.

\subsection{Correlation structure between different constructs}

Correlation assesses the strength as well as direction of the two variables' linear relationship. That is, it is the extent of the two variables' dependence or relationship. The correlation coefficient (r) value can vary between minus one and plus one, but a zero value indicates that the two variables have no relationship. Further, a value near zero suggests that the two variables have weak relationship and that they function more independently (Alia, 2017).

\subsection{Validation of research hypotheses by path analysis}

Path Analysis was also taken into account for examining and validating the research hypotheses. It is a statistical technique that helps assess a set of simultaneous regression equations and helps in surpassing the direct effects estimation (Alia, 2017).

\section{Analysis and presentation of results}

This section presents the analysis and results of the research in line with the research questions and hypotheses formulated in the study.

\subsection{Demographic analysis}

The instrument presents demographic variables including age, gender, academic level, experience, college, and major. As the figures show, out of the 260 respondents, 197 were female (75.8\%) and 63 males (24.2\%). Moreover, 46 respondents (17.7\%) were undergraduate students in their fifth level and formed the largest group. The second largest group involved 44 (16.9\%) first level students, followed by $33(12.7 \%)$ third level students, and $15(5.8 \%)$ and 13 (5.0\%) second and fourth level students, respectively. The education variable indicated that students were mostly undergraduates between first and tenth levels (Bachelor) while some 57 (21.9\%) were graduate students. $203(78.1 \%)$ respondents were undergraduates.

The students who were involved in this study had diverse majors (specialization) and were classified into three groups. The first group represented the Preparatory, numbered 55 $(21.2 \%)$; the second group, Information Systems, numbered $36(13.8 \%)$; and the third group 
included students from different majors. The semesters that utilised the Blackboard indicates that there were 119 (45.8\%) respondents with up to and above three semesters, forming the majority of the sample. Next, the second group included 70 (26.9\%) respondents with $0-1$ semester. Further, there were 120 (46.2\%) and 95 (36.9\%) respondents utilising the Blackboard always and regularly, respectively. According to these statistics, the students' experience with the Blackboard was moderate to advance.

\subsection{Descriptive statistics for UTAUT constructs}

The UTAUT model's variables adhered to a 5-point Likert scale, with 1 indicating strongly disagree and 5 indicating strongly agree. Variables having a mean score above 4 were regarded as having a higher expectancy or intention to use the Blackboard and those whose score was below 4 were regarded as having a low expectancy or intention to use the Blackboard. The constructs used for establishing PE, EE, SI, PF, FC, BI, and UB according to the UTAUT are presented in Tables 1-7.

Table 1 outlines the frequencies as well as corresponding percentages concerning the opinions of students in terms of PE. It can be observed that the students tend to believe that the Blackboard can help them complete their coursework at a faster pace. They also believe that the Blackboard can enhance their productivity and their possibility of obtaining a higher grade.

\section{Table 1}

Descriptive statistics for performance expectancy

\begin{tabular}{|c|l|l|l|l|l|l|l|}
\hline Item & $\begin{array}{c}\text { Strongly } \\
\text { disagree }\end{array}$ & \multicolumn{1}{|c|}{ Disagree } & Neutral & \multicolumn{1}{|c|}{ Agree } & $\begin{array}{c}\text { Strongly } \\
\text { agree }\end{array}$ & Mean & $\begin{array}{c}\text { Std. } \\
\text { deviation }\end{array}$ \\
\hline PE.1 & 9 & 12 & 36 & 113 & 90 & 4.0115 & .99218 \\
& $3.5 \%$ & $4.6 \%$ & $13.8 \%$ & $43.5 \%$ & $34.6 \%$ & & \\
\hline PE.2 & 8 & 20 & 45 & 124 & 63 & 3.8231 & .98612 \\
& $3.1 \%$ & $7.7 \%$ & $17.3 \%$ & $47.7 \%$ & $24.2 \%$ & & \\
\hline PE.3 & 9 & 36 & 74 & 90 & 51 & 3.5308 & 1.06317 \\
& $3.5 \%$ & $13.8 \%$ & $28.5 \%$ & $34.6 \%$ & $19.6 \%$ & & \\
\hline PE.4 & 19 & 25 & 69 & 80 & 67 & 3.5808 & 1.18110 \\
& $7.3 \%$ & $9.6 \%$ & $26.5 \%$ & $30.8 \%$ & $25.8 \%$ & & \\
\hline
\end{tabular}

Note. PE. 1 = I find the Blackboard useful in my study. PE. 2 = Using the Blackboard enables me to accomplish tasks more quickly. PE. 3 = Using the Blackboard in learning increases my productivity. PE. $4=$ Using the Blackboard in learning increases my chances of getting a good grade.

Source: From analysis results.

Table 2 presents a descriptive analysis concerning the students' opinions of Effort Expectancy. It can be seen that the students' expectancy is often that they will have 
understandable interaction with the Blackboard. They also often have a high expectancy that the system is not only easy for developing skills but also easy to learn and to use.

Table 2

Descriptive statistics for effort expectancy

\begin{tabular}{|l|l|l|l|l|l|l|l|}
\hline Item & $\begin{array}{c}\text { Strongly } \\
\text { disagree }\end{array}$ & \multicolumn{1}{|c|}{ Disagree } & \multicolumn{1}{|c|}{ Neutral } & \multicolumn{1}{c|}{ Agree } & $\begin{array}{c}\text { Strongly } \\
\text { agree }\end{array}$ & Mean & $\begin{array}{c}\text { Std. } \\
\text { deviation }\end{array}$ \\
\hline EE.1 & 7 & 34 & 34 & 105 & 80 & 3.8346 & 1.08676 \\
& $2.7 \%$ & $13.1 \%$ & $13.1 \%$ & $40.4 \%$ & $30.8 \%$ & & \\
\hline EE.2 & 10 & 24 & 45 & 117 & 64 & 3.7731 & 1.04274 \\
& $3.8 \%$ & $9.2 \%$ & $17.3 \%$ & $45.0 \%$ & $24.6 \%$ & & \\
\hline EE.3 & 6 & 23 & 36 & 115 & 80 & 3.9231 & 1.00282 \\
& $2.3 \%$ & $8.8 \%$ & $13.8 \%$ & $44.2 \%$ & 30.8 & & \\
\hline EE.4 & 3 & 11 & 29 & 129 & 88 & 4.1077 & .84512 \\
& $1.2 \%$ & $4.2 \%$ & $11.2 \%$ & $49.6 \%$ & $33.8 \%$ & & \\
\hline
\end{tabular}

Note. EE. $1=$ My interaction with the Blackboard is clear and understandable. EE. $2=$ It is easy for me to become skillful at using the Blackboard. EE.3 = I find the Blackboard easy to use. EE.4 = Learning to operate the Blackboard is easy for me.

Source: From analysis results.

Table 3 presents a descriptive analysis which indicates that those individuals whom students consider may not impact their use of the Blackboard, and that the students believe that the faculty and university provide them with sufficient support.

Table 3

Descriptive Statistics for Social Influence

\begin{tabular}{|l|l|l|l|l|l|l|l|}
\hline Item & $\begin{array}{c}\text { Strongly } \\
\text { disagree }\end{array}$ & \multicolumn{1}{c|}{ Disagree } & \multicolumn{1}{c|}{ Neutral } & \multicolumn{1}{c|}{ Agree } & $\begin{array}{c}\text { Strongly } \\
\text { agree }\end{array}$ & \multicolumn{1}{c|}{ Mean } & $\begin{array}{c}\text { Std. } \\
\text { deviation }\end{array}$ \\
\hline SI.1 & 21 & 48 & 111 & 64 & 16 & 3.0231 & 1.00166 \\
& $8.1 \%$ & $18.5 \%$ & $42.7 \%$ & $24.6 \%$ & $6.2 \%$ & & \\
\hline SI.2 & 21 & 52 & 96 & 69 & 22 & 3.0731 & 1.06109 \\
& $8.1 \%$ & $20.0 \%$ & $36.9 \%$ & $26.5 \%$ & $8.5 \%$ & & \\
\hline SI.3 & 19 & 48 & 39 & 104 & 50 & 3.4538 & 1.20239 \\
& $7.3 \%$ & $18.5 \%$ & $15.0 \%$ & $40.0 \%$ & $19.2 \%$ & & \\
\hline SI.4 & 7 & 19 & 61 & 119 & 54 & 3.7462 & .95708 \\
& $2.7 \%$ & $7.3 \%$ & $23.5 \%$ & $45.8 \%$ & $20.8 \%$ & & \\
\hline
\end{tabular}

Note. SI.1 = People who influence my behaviour think that I should use the Blackboard. SI. $2=$ People who are important to me think that I should use the Blackboard. SI. $3=$ Teachers in my classes have been helpful in the use of the Blackboard. SI.4 = The university has supported the use of the Blackboard.

Source: From analysis results.

Table 4 presents a descriptive analysis concerning the students' opinions of Perceived Functionality. It is evident that students often have a high expectancy concerning the Blackboard enabling them to control their learning activities. They also have a high expectancy 
regarding the system's flexible learning method concerning the time and place of use, its various multimedia course content, its diverse functionalities that support learning activities, as well as its course material presented in a readable and structured format.

\section{Table 4}

Descriptive Statistics for Perceived Functionality

\begin{tabular}{|l|l|l|l|l|l|l|l|}
\hline \multicolumn{1}{|c|}{ Item } & $\begin{array}{c}\text { Strongly } \\
\text { disagree }\end{array}$ & \multicolumn{1}{c|}{ Disagree } & \multicolumn{1}{c|}{ Neutral } & \multicolumn{1}{c|}{ Agree } & $\begin{array}{c}\text { Strongly } \\
\text { agree }\end{array}$ & Mean & $\begin{array}{c}\text { Std. } \\
\text { deviation }\end{array}$ \\
\hline PF.1 & 8 & 17 & 39 & 134 & 62 & 3.8654 & .95515 \\
& $3.1 \%$ & $6.5 \%$ & $15.0 \%$ & $51.5 \%$ & $23.8 \%$ & & \\
\hline PF.2 & 10 & 21 & 18 & 116 & 95 & 4.0192 & 1.05249 \\
& $3.8 \%$ & $8.1 \%$ & $6.9 \%$ & $44.6 \%$ & $36.5 \%$ & & \\
\hline PF.3 & 9 & 22 & 49 & 101 & 79 & 3.8423 & 1.05913 \\
& $3.5 \%$ & $8.5 \%$ & $18.8 \%$ & $38.8 \%$ & $30.4 \%$ & & \\
\hline PF.4 & 12 & 13 & 29 & 124 & 82 & 3.9654 & 1.02232 \\
& $4.6 \%$ & $5.0 \%$ & $11.2 \%$ & $47.7 \%$ & $31.5 \%$ & & \\
\hline PF.5 & 15 & 24 & 38 & 109 & 74 & 3.7808 & 1.12964 \\
& $5.8 \%$ & $9.2 \%$ & $14.6 \%$ & $41.9 \%$ & $28.5 \%$ & & \\
\hline PF.6 & 12 & 20 & 45 & 114 & 69 & 3.8000 & 1.06107 \\
& $4.6 \%$ & $7.7 \%$ & $17.3 \%$ & $43.8 \%$ & $26.5 \%$ & & \\
\hline
\end{tabular}

Note. PF. $1=$ The Blackboard allows me the control over my learning activities. PF. $2=$ The Blackboard offers flexibility in learning as to time and place of use. PF. 3 = The Blackboard offers multimedia (audio, video, and text) types of course content. PF.4 = The Blackboard provides different functionalities to support learning activities (present course materials, offer different communication and collaboration tools to communicate with faculty members and other students, taking tests, and submitting assignments and projects). PF. 5 = The Blackboard can present course material in a well-organized and readable format. PF. $6=$ The Blackboard can clearly present course content.

Source: From analysis results.

The descriptive statistics in Table 5 presents descriptive statistics which suggests that the students believe to an extent that they are provided with the required knowledge, resources, as well as support for using the system and that the Blackboard is compatible with their other systems. Moreover, as shown in Table 6, in the future, they intend to utilise the Blackboard. 


\section{Table 5}

\section{Descriptive Statistics for Facilitating Conditions}

\begin{tabular}{|c|c|c|c|c|c|c|c|}
\hline A. Item & $\begin{array}{ll}\text { B. } & \begin{array}{l}\text { Strongly } \\
\text { disagree }\end{array} \\
\end{array}$ & C. Disagree & D. Neutral & E. Agree & $\begin{array}{c}F . \quad \begin{array}{c}\text { Strongly } \\
\text { agree }\end{array} \\
\end{array}$ & G. Mean & $\begin{array}{c}H . \text { Std. } \\
\text { deviation }\end{array}$ \\
\hline $\begin{array}{ll}I . & \\
J . & \text { FC. } 1\end{array}$ & $\begin{array}{ll}K . & 7 \\
L . & 2.7 \%\end{array}$ & $\begin{array}{ll}\text { M. } & 15 \\
\text { N. } & 5.8 \%\end{array}$ & $\begin{array}{ll}O . & 21 \\
P . & 8.1 \%\end{array}$ & $\begin{array}{ll}Q . & 124 \\
R . & 47.7 \%\end{array}$ & $\begin{array}{ll}S . & 93 \\
T . & 35.8 \%\end{array}$ & $\begin{array}{ll}U . & \\
V . & 4.0808\end{array}$ & $\begin{array}{ll}W . & \\
X . & .95316\end{array}$ \\
\hline $\begin{array}{l}Y . \\
Z . \quad \text { FC. } 2 \\
A A .\end{array}$ & $\begin{array}{l}\text { BB. } 6 \\
C C .2 .3 \%\end{array}$ & $\begin{array}{l}\text { DD. } 17 \\
\text { EE. } 6.5 \%\end{array}$ & $\begin{array}{l}F F .27 \\
G G .10 .4 \%\end{array}$ & $\begin{array}{l}\text { HH. } 120 \\
\text { II. } \quad 46.2 \%\end{array}$ & $\begin{array}{ll}J J . & 90 \\
K K . & 34.6 \%\end{array}$ & 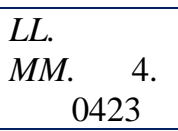 & $\begin{array}{l}N N . \\
O O . .95968\end{array}$ \\
\hline $\begin{array}{l}P P . \\
Q Q . \mathrm{FC} .3 \\
R R .\end{array}$ & $\begin{array}{ll}S S . & 9 \\
T T . & 3.5 \%\end{array}$ & $\begin{array}{l}U U .29 \\
V V .11 .2 \%\end{array}$ & $\begin{array}{lr}W W . & 38 \\
X X . & 14.6 \%\end{array}$ & $\begin{array}{ll}Y Y . & 111 \\
Z Z . & 42.7 \%\end{array}$ & $\begin{array}{cl}A A A . & 73 \\
B B B . & 28.1 \\
\% & \end{array}$ & $\begin{array}{l}C C C . \\
D D D . \quad 3 . \\
\quad 8077\end{array}$ & $\begin{array}{l}\text { EEE. } \\
F F F . \\
\quad 34\end{array}$ \\
\hline $\begin{aligned} & G G G . \\
& H H H . \text { FC. } \\
& 4 \\
& \text { III. } \\
&\end{aligned}$ & $\begin{array}{ll}\text { JJJ. } 32 & \\
\text { KKK. } & 12.3 \\
\% & \end{array}$ & $\begin{array}{ll}L L L . & 39 \\
M M M . & 15.0 \\
\% & \end{array}$ & $\begin{aligned} \text { NNN. } & 93 \\
\text { OOO. } & 35.8 \\
\% & \end{aligned}$ & $\begin{array}{ll}P P P . & 67 \\
Q Q Q . & 25 \\
.8 \% & \end{array}$ & $\begin{array}{lr}R R R . & 29 \\
S S S .11 .2 \%\end{array}$ & $\begin{array}{l}\text { TTT. } \\
\text { UUU. } 3 . \\
\quad 0846\end{array}$ & $\begin{array}{lr}V V . \\
W W W . & 1.159 \\
38 & \end{array}$ \\
\hline
\end{tabular}

Note. FC.1 = I have the resources necessary to use the Blackboard. FC.2 = I have the knowledge necessary to use the Blackboard. FC. 3 = The Blackboard is compatible with other systems I use. FC. 4 = A specific person (or group) is available for assistance with the Blackboard difficulties.

Source: From analysis results.

Table 6

Descriptive statistics for behavioral intention

\begin{tabular}{|l|l|l|l|l|l|l|l|}
\hline \multicolumn{1}{|c|}{ Item } & $\begin{array}{c}\text { Strongly } \\
\text { disagree }\end{array}$ & Disagree & Neutral & \multicolumn{1}{|c|}{ Agree } & $\begin{array}{c}\text { Strongly } \\
\text { agree }\end{array}$ & Mean & $\begin{array}{c}\text { Std. } \\
\text { deviation }\end{array}$ \\
\hline BI.1 & 14 & 30 & 43 & 115 & 58 & 3.6654 & 1.10787 \\
& $5.4 \%$ & $11.5 \%$ & $16.5 \%$ & $44.2 \%$ & $22.3 \%$ & & \\
\hline BI.2 & 13 & 23 & 44 & 114 & 66 & 3.7577 & 1.08292 \\
& $5.0 \%$ & $8.8 \%$ & $16.9 \%$ & $43.8 \%$ & $25.4 \%$ & & 1.15295 \\
\hline BI.3 & 15 & 34 & 45 & 103 & 63 & 3.6346 & \\
\end{tabular}

Note. BI.1 = I intend to use the Blackboard in the next semesters. BI.2= I predict I would use the Blackboard in the next semesters. BI.3 = I plan to use the Blackboard in the next semesters.

Source: From analysis results.

Table 7 shows that the students tend to agree regarding the efficiency of the Blackboard as a tool and that it can be adapted to modern devices such as various web browsers. On the other hand, they do not use this system on an everyday basis. 


\section{Table 7}

Descriptive statistics for use behavior

\begin{tabular}{|c|l|l|l|l|l|l|l|}
\hline Item & $\begin{array}{c}\text { Strongly } \\
\text { disagree }\end{array}$ & \multicolumn{1}{|c|}{ Disagree } & Neutral & \multicolumn{1}{c|}{ Agree } & $\begin{array}{c}\text { Strongly } \\
\text { agree }\end{array}$ & Mean & $\begin{array}{c}\text { Std. } \\
\text { deviation }\end{array}$ \\
\hline UB.1 & 45 & 87 & 41 & 58 & 29 & 2.7654 & 1.28353 \\
& $17.3 \%$ & $33.5 \%$ & $15.8 \%$ & $22.3 \%$ & $11.2 \%$ & & \\
\hline UB.2 & 17 & 31 & 45 & 119 & 48 & 3.5769 & 1.11754 \\
& $6.5 \%$ & $11.9 \%$ & $17.3 \%$ & $45.8 \%$ & $18.5 \%$ & & \\
\hline UB.3 & 14 & 28 & 37 & 110 & 71 & 3.7538 & 1.12920 \\
& $5.4 \%$ & $10.8 \%$ & $14.2 \%$ & $42.3 \%$ & $27.3 \%$ & & \\
\hline UB.4 & 10 & 38 & 49 & 108 & 55 & 3.6154 & 1.08968 \\
& $3.8 \%$ & $14.6 \%$ & $18.8 \%$ & $41.5 \%$ & $21.2 \%$ & & \\
\hline
\end{tabular}

Note. UB. 1 = I will use the Blackboard on a daily basis. UB.2 = I will use the Blackboard because it is an effective tool. UB.3 = I will use the Blackboard because it is adapted to modern devices (Tablet, Laptop, Desktop, and Phones). UB.4 = I will use the Blackboard on different web browsers.

Source: From analysis results.

\subsection{Testing the correlations between the UTAUT constructs}

The correlations between the seven factors were also a point of interest for this research. Although several studies that used UTAUT have explored the correlation between PE and EE, the present research explored the correlations between each of the factors. Hence, a Pearson Correlation was conducted to explore these relations. 


\section{Table 8}

Correlations between the model constructs

\begin{tabular}{|c|c|c|c|c|c|c|c|c|}
\hline & & PE & $\mathbf{E E}$ & SI & PF & FC & BI & UB \\
\hline \multirow[t]{3}{*}{ PE } & Pearson Correlation & 1 & $.464^{* *}$ & $.527^{* *}$ & $.658^{* *}$ & $.562^{* *}$ & $.664^{* *}$ & $.739^{* *}$ \\
\hline & Sig. (2-tailed) & & .000 & .000 & .000 & .000 & .000 & .000 \\
\hline & $\mathrm{N}$ & 260 & 260 & 260 & 260 & 260 & 260 & 260 \\
\hline \multirow[t]{3}{*}{$\mathrm{EE}$} & Pearson Correlation & $.464^{* *}$ & 1 & $.350^{* *}$ & $.567^{* *}$ & $.689^{* *}$ & $.331^{* *}$ & $.551^{* *}$ \\
\hline & Sig. (2-tailed) & .000 & & .000 & .000 & .000 & .000 & .000 \\
\hline & $\mathrm{N}$ & 260 & 260 & 260 & 260 & 260 & 260 & 260 \\
\hline \multirow[t]{3}{*}{ SI } & Pearson Correlation & $.527^{* *}$ & $.350^{* *}$ & 1 & $.494^{* *}$ & $.429^{* *}$ & $.513^{* *}$ & $.547^{* *}$ \\
\hline & Sig. (2-tailed) & .000 & .000 & & .000 & .000 & .000 & .000 \\
\hline & $\mathrm{N}$ & 260 & 260 & 260 & 260 & 260 & 260 & 260 \\
\hline \multirow[t]{3}{*}{$\mathrm{PF}$} & Pearson Correlation & $.658^{* *}$ & $.567^{* *}$ & $.494^{* *}$ & 1 & $.691^{* *}$ & $.567^{* *}$ & $.707^{* *}$ \\
\hline & Sig. (2-tailed) & .000 & .000 & .000 & & .000 & .000 & .000 \\
\hline & $\mathrm{N}$ & 260 & 260 & 260 & 260 & 260 & 260 & 260 \\
\hline \multirow[t]{3}{*}{$\mathrm{FC}$} & Pearson Correlation & $.562^{* *}$ & $.689^{* *}$ & $.429^{* *}$ & $.691^{* *}$ & 1 & $.462^{* *}$ & $.664^{* *}$ \\
\hline & Sig. (2-tailed) & .000 & .000 & .000 & .000 & & .000 & .000 \\
\hline & $\mathrm{N}$ & 260 & 260 & 260 & 260 & 260 & 260 & 260 \\
\hline \multirow[t]{3}{*}{ BI } & Pearson Correlation & $.664^{* *}$ & $.331^{* *}$ & $.513^{* *}$ & $.567^{* *}$ & $.462^{* *}$ & 1 & $.659^{* *}$ \\
\hline & Sig. (2-tailed) & .000 & .000 & .000 & .000 & .000 & & .000 \\
\hline & $\mathrm{N}$ & 260 & 260 & 260 & 260 & 260 & 260 & 260 \\
\hline \multirow[t]{3}{*}{ UB } & Pearson Correlation & $.739^{* *}$ & $.551^{* *}$ & $.547^{* *}$ & $.707^{* *}$ & $.664^{* *}$ & $.659^{* *}$ & 1 \\
\hline & Sig. (2-tailed) & .000 & .000 & .000 & .000 & .000 & .000 & \\
\hline & $\mathrm{N}$ & 260 & 260 & 260 & 260 & 260 & 260 & 260 \\
\hline
\end{tabular}

**. Correlation is significant at the 0.01 level ( 2 tailed).

Source: from analysis results.

Table 8 illustrates that there are strong correlations between most constructs. In particular, there is a strong positive relationship between PE and the variables SI, PF, FC, BI, and UB. This means that one variable's effect is strongly correlated with that of the other variables, with Pearson's $\mathrm{r}=.527, .658, .562, .664$, and .739 for SI, PF, FC, BI, and UB, respectively, at the significant level $\mathrm{p}<0.01$. Similarly, the table above shows the significant positive correlation of EE with PF $(r=.567), F C(r=.689)$, and UB $(r=.551)$. However, this correlation decreases when it is associated with PE $(r=.464)$, SI $(r=.350)$, and BI $(r=.331)$. Although SI has strong positive relationships with PE $(\mathrm{r}=.527)$, BI $(\mathrm{r}=.513)$, and UB $(\mathrm{r}=$ $.547)$, it has a weak positive correlation with $\mathrm{EE}(\mathrm{r}=.350)$. Moreover, PF has a relatively strong positive relationship with UB $(\mathrm{r}=.707), \mathrm{FC}(\mathrm{r}=.691), \mathrm{PE}(\mathrm{r}=.658), \mathrm{EE}(\mathrm{r}=.567)$, and $\mathrm{BI}(\mathrm{r}$ $=.567)$. Moreover, FC has a strong positive relationship with UB $(\mathrm{r}=.664)$ and medium 
positive relationship with BI $(r=.462)$, while BI has a positive relationship with UB $(r=.659)$. In addition, UB has a strong positive relationship with all factors.

\subsection{Data analysis techniques to test the hypotheses}

The present study intends to determine whether the single and multiple variable sets have any relationship and identify the main factors concerning the research problem. The study also implemented techniques according to the research model. It is necessary to determine relationships which may be present among the variables chosen to affect the model for addressing the research question. Further, for validating the research model and assessing the hypotheses to examine the suggested variables' relationships, the methods were chosen according to the proposed model and the variables' direct effect considering their proposed hypotheses.

\subsubsection{Regression analysis}

Chatterjee and Hadi (2013) (Chatterjee \& Simonoff, 2013), stated that regression analysis evaluates the relationship among variables. It is a statistical approach implemented for examining functional relationship between two or more dependent as well as independent variables for estimating the extent of a variable's existence based on the condition of one or multiple other constructs.

In this study, the research conceptual model included two sets of regressions. The first model included four hypotheses to examine the relationships between external variables including PE, EE, SI, and PF as the independent variables and $\mathrm{BI}$ as the dependent variable. The second set of regression included two hypotheses to examine the relationships between FC and $\mathrm{BI}$ as the independent variables and UB as the dependent variable.

The present study included external variables, which are independent, presented in the research model which intend to estimate the BI concerning using the Blackboard as well as UB. Hence, multiple regressions are best suited for this analysis as it can address the research questions. In order to test the six hypotheses, a multiple regression analysis was used. For this part, four types of data are generated from the regression analysis.

The first type of data is B which stands for Beta standardized coefficient. The Beta coefficients are the estimates that result from an analysis involving an independent variable that has been standardized to a variance of one. A coefficient is standardized when a researcher aims to know the extent of effect or the value of an independent variable on the dependent variable 
in a multiple regression analysis process. The second item is the Beta which stands for standardized Beta coefficient. Beta indicates the extent of alternative independent predictors. Though B data have been used for this research, Betas are typically used to weigh different B coefficients to determine which one has a greater impact on the overall dependent value. The regression analysis has provided also ANNOVA table and the only information used in the Pvalue that stands for the Significance level of value attributed to a dependent variable from the predictors. This value is commonly set at .05 , and when Sig. value is less than this number, it is a significant effect on the dependent variable; otherwise, there will be no significant influence.

Another key item that has been considered to understand the intention to accept and use the Blackboard is the R Square. This item is described as the percentage of variable variation resulting from its independent variables (Draper\& Smith, 1998). This is explained by a linear model. Depending on the researcher's choice and the research size as well as the amount of collected data, someone can use either R Square or Adjusted R Square. Using the data from the regression analysis, the six hypotheses were tested.

\subsubsection{Behavioural Intention to use (BI) and its independent variables}

The survey instrument was designed with reference to the original UTAUT model. Thus, the first regression analysis measured the relationship between four independent variables (PE, EE, SI, and PF) and one dependent variable (BI) as in Table 9. Results from the analysis indicated that the B coefficients or weights for PE, EE, SI, and PF concerning the students' BI were $.560,(.078), .272$, and .264 , respectively, and the P-values were $.000, .227, .000$, and .001 , respectively. Thus, PE, SI, and PF had significant impacts on BI. By comparing the B coefficients for PE, EE, SI, and PF, it can be seen that PE had a greater impact on students' BI towards the Blackboard. It was also indicated that PE, EE, SI, and PF had a combined R2 Square of .498 , thus explaining $49.8 \%$ of the variance in $\mathrm{BI}$ because of its independent variables (PE, EE, SI, and PF). Based on the analysed data, H1, H3, and H4 were supported as their P-values were less than .05, whereas H2 was not supported as its P-value for EE was .227, which was greater than .05 , and thus, its weight on BI was not statistically significant. 
Table 9

Multiple Regression Analysis on Dependent Variable BI

\begin{tabular}{|c|c|c|c|c|c|c|}
\hline Constructs and hypothesis & Code & B & Beta & R Square & Sig. (P-Value) & Result \\
\hline \multicolumn{7}{|l|}{$\mathrm{PE}-\mathrm{BI}$} \\
\hline $\begin{array}{l}\text { Performance expectancy will } \\
\text { positively affect students'behavioural } \\
\text { intention to use LMS. }\end{array}$ & H1 & .560 & .455 & \multirow{6}{*}{.498} & 0.000 & Supported \\
\hline \multicolumn{7}{|l|}{$\mathrm{EE}-\mathrm{BI}$} \\
\hline $\begin{array}{l}\text { Effort expectancy will positively } \\
\text { influence students' } \\
\text { intention toward LMS. }\end{array}$ & $\mathrm{H} 2$ & $-.078-$ & -.066 & & 0.227 & $\begin{array}{l}\text { Not } \\
\text { Supported }\end{array}$ \\
\hline \multicolumn{6}{|l|}{$\mathrm{SI}-\mathrm{BI}$} & \\
\hline $\begin{array}{l}\text { A high level of social influence will } \\
\text { positively influence the } \\
\text { students'behavioural intention. }\end{array}$ & $\mathrm{H} 3$ & .272 & .193 & & 0.000 & Supported \\
\hline \multicolumn{6}{|l|}{$\mathrm{PF}-\mathrm{BI}$} & \\
\hline $\begin{array}{l}\text { A high level of perceived } \\
\text { functionality will positively influence } \\
\text { the students' behavioural intention. }\end{array}$ & $\mathrm{H} 4$ & .264 & 210 & & 0.001 & Supported \\
\hline
\end{tabular}

Source: From analysis results.

\subsubsection{Use Behavior (UB) and independent variables FC and BI}

The second regression analysis examined the relationships between UB as a dependent variable and FC and BI as independent variables as in Table 10. Every independent variable's B coefficients were .526 and .389 for FC and BI, respectively. Moreover, R2 = .599 suggests that a high variance at $59.9 \%$ can be explained based on the independent variables (FC and $\mathrm{BI}$ ). The independent variables, which are FC and BI, significantly impact UB. These statements were confirmed by their P-value of .000 which was less than .05 . From these results, it can be concluded that there is a positive relationship between UB as the dependent variable and the independent variables, FC and BI. The present results showed that attitude is significantly impacted by FC $(\mathrm{B}=0.526)$ than by $\mathrm{BI}(\mathrm{B}=0.389)$. Therefore, with reference to the above described data, H5 and H6 are supported. 
Table 10

Multiple Regression Analysis on Dependent Variable UB

\begin{tabular}{|c|c|c|c|c|c|c|}
\hline Constructs and hypothesis & Code & B & Beta & R Square & $\begin{array}{c}\text { Sig. (P- } \\
\text { Value) }\end{array}$ & Result \\
\hline \multicolumn{6}{|l|}{$\mathrm{FC}-\mathrm{UB}$} & \\
\hline $\begin{array}{l}\text { A high perceived level of LMS } \\
\text { technologies infrastructure (LMSI) will } \\
\text { influence the level of acceptance and use } \\
\text { of LMS positively. }\end{array}$ & H5 & .526 & .457 & & .000 & Supported \\
\hline \multicolumn{6}{|l|}{$\mathrm{BI}-\mathrm{UB}$} & \\
\hline $\begin{array}{l}\text { Students' positive behavioral intention } \\
\text { will have a positive influence on LMS } \\
\text { acceptance and usage. }\end{array}$ & H6 & .389 & .448 & & .000 & Supported \\
\hline
\end{tabular}

Source: From analysis results.

\section{Figure 2}

Predictive Path Model and R Square and B Coefficients

Independent Variables

Dependent Variables

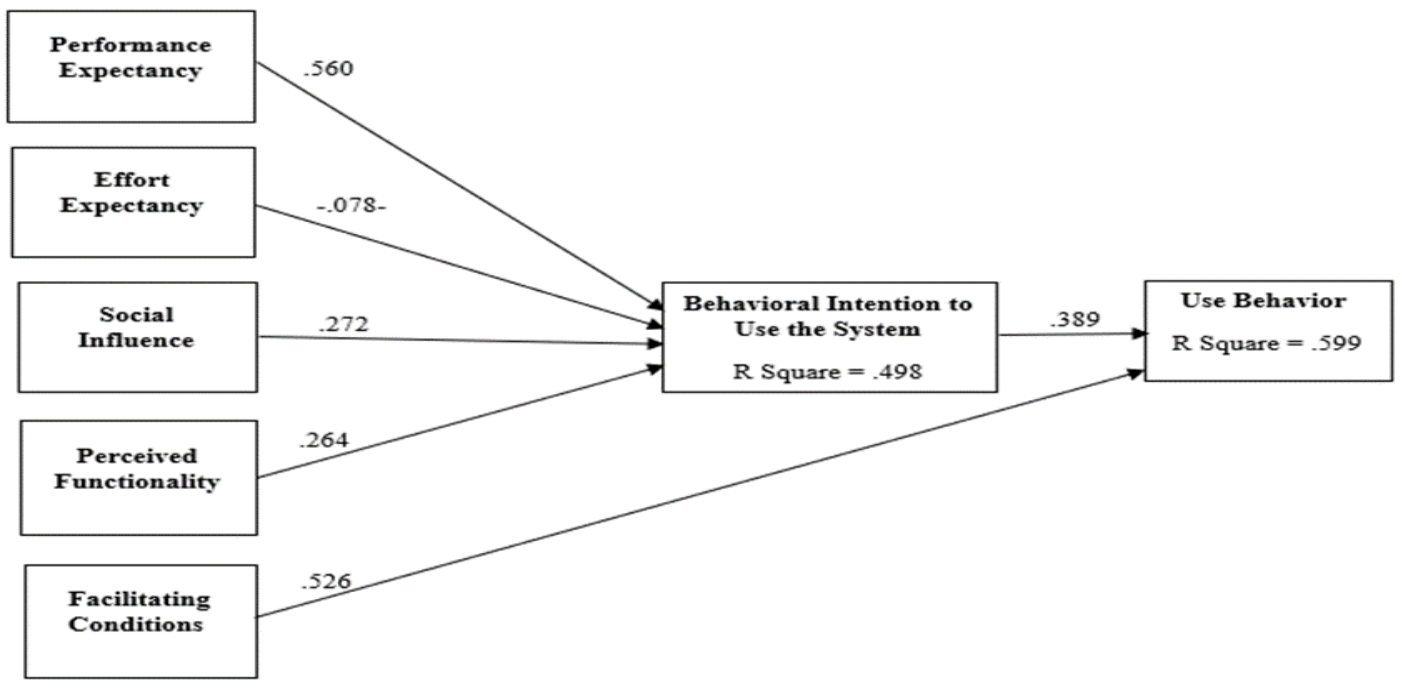

Source: From analysis results.

\section{Discussion}

This section examines the findings that address this study's research question. Hence, this section discusses the research question by explaining the critical factors that influence students' acceptance of using LMS through using the UTAUT model in Saudi Arabia. Moreover, this section presenting the relationship between the factors of students' acceptance, as measured by the UTAUT model in order to provide in depth understanding of the factors. 


\subsection{The influence of UTAUT constructs on Blackboard acceptance}

Performance Expectancy: PE has been defined as 'the degree to which an individual believes that using a given technology will help him/her to attain gains in job performance' (Venkatesh, et al., 2003). The data analysis results show that PE has a positive relationship with BI. The study found that PE has a greater impact on BI with $\mathrm{B}=.560$ and $\mathrm{P}=.000$. This finding is consistent with the findings of previous studies (Venkatesh \& Davis, 2000), (Dečman, 2015), (Sattari, et al., 2017).

Effort Expectancy: Effort expectancy refers to 'the degree to which a person believes that using a particular system would be free of mental effort' (Venkatesh, et al., 2003). It is evident that $\mathrm{EE}$ has a direct positive influence on intentions to use technology technology (Sattari, et al., 2017), (Juhary, 2014), (Mabed \& Koehler, 2012). More specifically, earlier research has demonstrated that perceived EE is a crucial factor in students' intention to use e-learning (Wang \& Wang, 2008). However, in this research, results showed certain inconsistencies with these previous studies. Further, the influence of EE on students' intentions to use e-learning was negative, which means that the students faced difficulties in using the Blackboard for their learning activities.

Social Influence: Social influence refers to the extent to which individuals think that others believe that they should act in a certain manner (Venkatesh, et al., 2003). In this research, however, the SI concerns using the Blackboard in terms of the friends' and faculty members' influences on their intention to using it. Earlier research contended that SI is a strong predictor of BI to use new technology (Venkatesh \& Davis, 2000), (Mabed \& Koehler, 2012).

Perceived Functionality: Perceived functionality concerns the perceived ability of the system and the activities that students undertake with the LMS such as 'accessing course contents, communication, and self-assessment' (Bousbahi \& Alrazgan, 2015). The analysis showed that PF has a direct impact on students' BI. As the students believe that the Blackboard provides them with different and basic functions which, in return, facilitate and enhance their learning processes.

Facilitating Conditions: Facilitating conditions concerns the extent of the individual's belief that the infrastructure as well as institution provide support for using the innovation [38]. Four indicators for FC regarding the use of the Blackboard were considered in this study which included the resources and knowledge necessary for using it, the existence of a dedicated team, and the university administration's 
encouragement to use the Blackboard. In this research, there is a strong and positive impact of FC on student's acceptance and the use of the Blackboard with $\mathrm{B}=.526$ and $\mathrm{P}=.000$. Venkatesh et al. (2003) (Venkatesh, et al., 2003), noted that if e-learning is supported by an organizational and technical infrastructure, then there is a greater probability of the learners to implement e-learning more frequently for their learning activities. In line with earlier studies (Venkatesh, et al., 2003), (Sattari, et al., 2017), (Fianu, et al., 2018), the present study also observed that FC were the second highest predictor of students' acceptance of e-learning.

Behavioral Intention: Behavioural intention (BI) is the extent to which a person develops an attitude toward technology (Byungura, 2015). Therefore, to measure the level of acceptance and use of LMS, it was hypothesized that students' BI will affect the LMS' acceptance. The study found that there is a direct impact of BI on using the Blackboard.

\subsection{Correlation between UTAUT constructs}

Additional analysis tests were conducted to determine the significance of the relationships between the seven factors as an additional theme of interest to this research. The data presented in table 4.13 shows that most constructs are significantly correlated. A strong positive relationship was found between the PE variable and the SI, PF, FC, BI, and UB variables, which means that the effect of one variable is strongly correlated with that of a number of other variables. As stated earlier, several studies examining the relationship between PE and EE have reached similar conclusions (Venkatesh, et al., 2003), (Wang \& Wang 2008) to those of this research and have noted a medium positive correlation between the two $(\mathrm{r}=$ $.464, \mathrm{n}=260, \mathrm{p}=.000$ ). The level of PE is associated with the level of EE. That is, the students who perceived the Blackboard to be beneficial and effective also sometimes perceived it to be easy to use. The implication of this finding is that universities must focus more on providing students with training sessions so that they can take advantage of this system.

However, there is no research that examines the correlation between PF and other factors as this factor was added to extend the UTAUT model. This thesis has shown that there is a strong relationship between PF and UB $(r=.707), \mathrm{FC}(\mathrm{r}=.691), \mathrm{PE}(\mathrm{r}=.658), \mathrm{EE}$, and $\mathrm{BI}(\mathrm{r}=$ .567). This relationship means that the students who perceived the functionality of the Blackboard were also more likely to perceive that there was a good environment for them to use the Blackboard, and those perceiving the system's usefulness for their performance were 
more likely to use the Blackboard. In addition, there is a significant positive correlation between UB and other factors. The existence of this strong relationship means that the students who use the Blackboard believe that they gain benefits, it affects their performance, it is easy to use and deal with, they are influenced by their family and friends, they believe that the Blackboard provides different functions, and there is a good environment for them to implement the system.

According to effort expectancy, it has a weak relationship with SI and BI, which means that the students who believe the Blackboard is easy to use are not likely perceive the current environment to be supportive of its use. A study performed by Salloum and Shaalan (2018) also revealed that effort expectancy was not suggested to provide a significant impact on students' intention towards E-learning system (Salloum \& Shaalan, 2018).

\subsection{Impact of main finding}

In this study, the multiple regression analysis results were regarded as the major assessment of the variables' impact on the research model. The main determinants impacting students' BI of accepting and using the Blackboard are PE, PF, FC and SI. These determinants were significant and had a direct influence on students' Behavioral Intention to use Blackboard.

The independent variables' impact on the dependent variables was also evaluated for generating further discussion so that the variables' predictive ability in the research model could be examined. It was verified that PE is the major determinant of the independent variables' intention to use. Furthermore, FC is the second highest predictor of students' acceptance and use of the Blackboard. The result also found that EE does not impact the students' BI.

It can be concluded that the impact of these main findings, the management of King Abdulaziz University should pay attention to the PE, PF, FC and SI factors in research model in order to enhance the students' acceptance of using Blackboard.

\section{Conclusion and future work}

This section concludes the study by elaborating the contributions as well as the limitation and future work.

\subsection{Limitation}

The study effectively addressed the research question to an extent as it determined the critical factors as well as their relationships which impact the students' acceptance of using 
LMS. For this, the UTAUT model was used in Saudi Arabia. On the other hand, this study involved various limitations that were also observed in other studies in the same research field:

- The study's range is restricted to one university (King Abdulaziz University), because of which the findings may not generalizable for all Saudi Arabia universities.

- The study is restricted by time as the instrument was distributed among the students at the end of the semester and the beginning of the next semester.

- In the present study, only the quantitative method was used, which was also restricted to the previous UTAUT studies' predefined instrument. This can hinder the findings which rely on the participants' answers, based on which the findings can only deliver the reasons behind 'what' and restrict an extensive understanding of the detailed 'why' behind the participants' perceptions.

- The study is primarily focused on the UTAUT's major constructs and does not moderate variables, which can considerably impact the students' perceptions regarding accepting and using e-learning.

\subsection{Future work}

In the future, another study should be extended with the following issues:

- to generalise the results by extending the research to different universities in Saudi Arabia

- to include as many students from various semester, different universities as respondents in order to get in depth understanding of affecting factors in students' acceptance in using blackboard

- to use different methods to test the research model.

- to incorporate different moderating variables which may provide in-depth knowledge to understand the variables that can affect the students' perception to accept and use the Blackboard.

\subsection{Conclusion}

This study is conducted to examine the students' acceptance and use of the Blackboard and to explore the factors that may affect their intention in King Abdulaziz University. Thus, a research model is proposed that involves independent variables: "Effort Expectancy 
(EE), Performance Expectancy (PE), Perceived Functionality (PF), Facilitating Condition (FC), Social Influence (SI), and the dependent variables including: Behavioral Intention to use (BI), and Usage Behavior". Perceived Functionality (PF) construct was used to extent the model.

The contributions of this study are as follows:

- The study developed and validated a theoretical research model based on UTAUT to understand students' acceptance of using the Blackboard in King Abdulaziz University.

- The study extended the UTAUT model by adding a new factor of Perceived Functionality (PF).

- The study validated the instrument's Arabic version, which is a reliable validation and can help the instrument to be implemented for future studies concerning e-learning technology acceptance in the Arabic region.

- This study not only contributes to the overall information system research area but also adds particularly to the user acceptance research area while being acknowledged in the research community.

The study contributes to the body of knowledge in developing the conceptual research model using the Unified Theory of Acceptance and Use of Technology (UTAUT) model in measuring the students' intention in using Blackboard in King Abdulaziz University. As a conclusion, this study contributes to the initial work in understanding and discovering the Saudi Arabia students' intention in using Blackboard by facilitating the UTAUT model.

\section{References}

Al-Adwan, A., Al-Adwan, A. \& Smedley, J., (2013), Exploring students acceptance of elearning using Technology Acceptance Model in Jordanian universities. International Journal of Education and Development using ICT. 9(2).

http://ijedict.dec.uwi.edu//viewarticle.php?id=1617

Al-Busaidi, K.A. \& Al-Shihi, H., (2010), Instructors' acceptance of learning management systems: A theoretical framework. Communications of the IBIMA, 2010(2010): p. 110. https://ibimapublishing.com/articles/CIBIMA/2010/862128/

Alharbi, S. \& Drew, S., (2014), Using the technology acceptance model in understanding academics' behavioural intention to use learning management systems. International 
Journal of Advanced Computer Science and Applications. 5(1): p. 143-155. https://dx.doi.org/10.14569/IJACSA.2014.050120

Alia, A., (2017), An investigation of the application of the Technology Acceptance Model (TAM) to evaluate instructors' perspectives on E-Learning at Kuwait University, Dublin City University. http://doras.dcu.ie/21586/

Alkhattabi, M., Neagu, D., \& Cullen, A., (2011), Assessing information quality of e-learning systems: a web mining approach. Computers in Human Behavior, 27(2): p. 862-873. https://doi.org/10.1016/j.chb.2010.11.011

Almaiah, M.A., Al-Khasawneh, A., \& Althunibat, A., (2020), Exploring the critical challenges and factors influencing the E-learning system usage during COVID-19 pandemic. Education and Information Technologies, p. 1. https://doi.org/10.1007/s10639-020-10219-y

Alshehri, A., Rutter, M.J., \& Smith, S., (2019), An implementation of the UTAUT model for understanding Students' perceptions of learning management systems: A study within tertiary institutions in Saudi Arabia. International Journal of Distance Education Technologies (IJDET). 17(3): p. 1-24. https://doi.org/10.4018/IJDET.2019070101

Bhrommalee, P., (2011), Student acceptance of web-based learning: A quantitative analysis within a public university in Thailand, Walden University. https://www.learntechlib.org/p/120983/.

Bouhnik, D. \& Marcus, T., (2006), Interaction in distance-learning courses. Journal of the American Society for Information Science and Technology. 57(3): p. 299-305. https://doi.org/10.1002/asi.20277

Bousbahi, F. \& Alrazgan, M.S., (2015), Investigating IT faculty resistance to learning management system adoption using latent variables in an acceptance technology model. The Scientific World Journal, 2015. https://doi.org/10.1155/2015/375651

Buabeng-Andoh, C. \& Baah, C., (2019), Investigating the actual usage of learning management system: From perspectives of University students. in 2019 International Conference on Computing, Computational Modelling and Applications (ICCMA). IEEE. http://ir.uew.edu.gh/xmlui/handle/123456789/264

Byungura, J.C. (2015), E-learning management system for thesis process support from a supervisor perspective: The case of SciPro System at University of Rwanda, Jönköping University: Sweden. http://hj.divaportal.org/smash/record.jsf?pid=diva2\%3A840593\&dswid=-9660

Carmines, E.G. \& Zeller, R.A., (1979), Reliability and validity assessment. Vol. 17: Sage publications. https://dx.doi.org/10.4135/9781412985642

Chao, C.-M., (2019), Factors determining the behavioral intention to use mobile learning: An application and extension of the UTAUT model. Frontiers in psychology. 10: p. 1652. https://doi.org/10.3389/fpsyg.2019.01652 
Chatterjee, S. \& Simonoff, J.S., (2013), Handbook of regression analysis. Vol. 5: John Wiley \& Sons. https://doi.org/10.1111/insr.12020_22

Claar, C., Portolese Dias, L., \& Shields, R., (2014), STUDENT ACCEPTENCE OF LEARNING MANAGEMENT SYSTEMS: A STUDY ON DEMOGRAPHICS. Issues in Information Systems. 15(1). https://doi.org/10.48009/1_iis_2014_409-417

Dečman, M., (2015), Modeling the acceptance of e-learning in mandatory environments of higher education: The influence of previous education and gender. Computers in human behavior. 49: p. 272-281. https://doi.org/10.1016/j.chb.2015.03.022

Draper, N.R. \& Smith, H., (1998), Applied regression analysis. Vol. 326., John Wiley \& Sons. https://www.wiley.com/en-us/Applied+Regression+Analysis\%2C+3rd+Editionp-9780471170822

Dutton, J., Dutton, M., \& Perry, J., (2001), Do online students perform as well as lecture students? Journal of Engineering education,. 90(1): p. 131-136. https://doi.org/10.1002/j.2168-9830.2001.tb00580.x

Estriegana, R., Medina-Merodio, J.-A., \& Barchino, R., (2019), Student acceptance of virtual laboratory and practical work: An extension of the technology acceptance model. Computers \& Education. 135: p. 1-14. https://www.learntechlib.org/p/208189/

Farahat, T., (2012), Applying the technology acceptance model to online learning in the Egyptian universities. Procedia-Social and Behavioral Sciences. 64: p. 95-104. http://dx.doi.org/10.1016/j.sbspro.2012.11.012

Fianu, E., et al., (2018), Factors affecting MOOC usage by students in selected Ghanaian universities. Education Sciences. 8(2): p. 70. https://doi.org/10.3390/educsci8020070

Juárez Santiago, B., et al., (2020), Learning Management System-Based Evaluation to Determine Academic Efficiency Performance. Sustainability. 12(10): p. 4256. https://doi.org/10.3390/su12104256

Juhary, J., (2014), Perceived Usefulness and Ease of Use of the Learning Management System as a Learning Tool. International Education Studies. 7(8): p. 23-34. http://dx.doi.org/10.5539/ies.v7n8p23

Liu, S.-H., Liao, H.-L., \& Peng, C.-J., (2005), Applying the technology acceptance model and flow theory to online e-learning users' acceptance behavior. E-learning. 4(H6): p. H8. https://doi.org/10.48009/2_iis_2005_175-181

Mabed, M. \& Koehler, T., (2012), An empirical investigation of students' acceptance of OLAT as an open web-based learning system in an Egyptian Vocational Education School. International Journal of Web-Based Learning and Teaching Technologies (IJWLTT). 7(1): p. 36-53. https://doi.org/10.4018/jwltt.2012010103

Malhotra, N. \& Birks, D., (2007), Marketing Research: an applied approach: 3rd European Edition: Pearson education. http://dx.doi.org/10.1108/S1548-6435(2006)2 
Moreno, V., Cavazotte, F., \& Alves, I., (2017), Explaining university students' effective use of e-learning platforms. British Journal of Educational Technology. 48(4): p. 995-1009. https://doi.org/10.1111/bjet.12469

Paulsen, M.F., (2002), Online education systems: Discussion and definition of terms. NKI distance education. 202: p. 1-8. https://www.porto.ucp.pt/open/curso/modulos/doc/Definition\%20of\%20Terms.pdf

Paulsen, M.F., (2003), Experiences with learning management systems in 113 European institutions. Journal of Educational Technology \& Society. 6(4): p. 134-148. http://ifets.ieee.org/periodical/6_4/13.pdf

Pituch, K.A. \& Lee, Y.-k., (2006), The influence of system characteristics on e-learning use. Computers \& Education. 47(2): p. 222-244. https://doi:10.1016/j.compedu.2004.10.007

Rahman, N., Rosman, A. \& Sahabudin N., (2020),. Students' Continuance of Using ELearning System: A Review of Conceptual Frameworks. in IOP Conference Series: Materials Science and Engineering. IOP Publishing. http://dx.doi.org/10.1088/1757899X/769/1/012044

Revythi, A. \& Tselios, N., (2017), Extension of Technology Acceptance Model by using System Usability Scale to assess behavioral intention to use e-learning. Education and Information Technologies. 24(4): p. 2341-2355. https://doi.org/10.1007/s10639-01909869-4

Saade, R., F. Nebebe, \& Tan, W., (2007), Viability of the" technology acceptance model" in multimedia learning environments: A comparative study. Interdisciplinary Journal of E-Learning and Learning Objects. 3(1): p. 175-184. http://dx.doi.org/10.28945/392

Saadé, R.G. \& Kira, D., (2006), The emotional state of technology acceptance. Issues in Informing Science \& Information Technology,. 3. http://dx.doi.org/10.28945/913

Salloum, S.A. \& Shaalan, K., (2018), Factors affecting students' acceptance of e-learning system in higher education using UTAUT and structural equation modeling approaches. in International Conference on Advanced Intelligent Systems and Informatics. 2018. Springer. https://doi.org/10.1007/978-3-319-99010-1_43

Sattari, A., Abdekhoda, M. \& Zarea Gavgani, V., (2017), Determinant factors affecting the web-based training acceptance by health students, applying UTAUT model. International Journal of Emerging Technologies in Learnming. 12(10): p. 112-126. https://doi.org/10.3991/ijet.v12i10,7258

Schumacker, R.E. \& Lomax, R.G., (2004), A beginner's guide to structural equation modeling, psychology press. http://dx.doi.org/10.4324/9781410610904

Shen, D., et al., (2006), Social influence for perceived usefulness and ease-of-use of course delivery systems. Journal of Interactive Online Learning. 5(3): p. 270-282. https://www.ncolr.org/jiol/issues/pdf/5.3.4.pdf 
Stage, F.K., (1988), University attrition: LISREL with logistic regression for the persistence criterion. Research in Higher Education. 29(4): p. 343-357. https://doi.org/10.1007/BF00992775

Swesi, K., (2012), An Investigation into the Influence of Learning Styles and other Factors Affecting Students' Perception of Virtual Learning Environments. https://dora.dmu.ac.uk/handle/2086/7105

Tarhini, A., et al., (2015), Towards the Acceptance of RSS to Support Learning: An empirical study to validate the Technology Acceptance Model in Lebanon. Electronic Journal of e-Learning. 13(1): p. 30-41. https://files.eric.ed.gov/fulltext/EJ1051840.pdf

Tarhini, A., et al., (2017), Examining the moderating effect of individual-level cultural values on users' acceptance of E-learning in developing countries: a structural equation modeling of an extended technology acceptance model. Interactive Learning Environments. 25(3): p. 306-328. https://doi.org/10.1080/10494820.2015.1122635

Ülker, D. \& Y1lmaz Y., (2016), Learning management systems and comparison of open source learning management systems and proprietary learning management systems. Journal of systems integration. 7(2): p. 18-24. http://dx.doi.org/10.20470/jsi.v7i2.255

Vasanthi Muniasamy, D., Ejalani, I.M., \& Anandhavalli M., (2014), Prediction of Learner Perception and Acceptance of E-Learning System for Learning with TAM (Technology Acceptance Model) in King Khalid University, Kingdom of Saudi Arabia. International Journal of Emerging Technology and Advanced Engineering. https://www.semanticscholar.org/paper/Prediction-of-Learner-Perception-andAcceptance-of-Muniasamy-Eljailani/91a6aa9f311b7b90e65d74fd1c1513302fb41c2a

Venkatesh, V. \& Davis, F.D., (2000), A theoretical extension of the technology acceptance model: Four longitudinal field studies. Management science. 46(2): p. 186-204. http://dx.doi.org/10.1287/mnsc.46.2.186.11926

Venkatesh, V., et al., (2003), User acceptance of information technology: Toward a unified view. MIS quarterly: p. 425-478. http://dx.doi.org/10.2307/30036540

Wang, H.Y. \& Wang, Y.S., (2008), Gender differences in the perception and acceptance of online games. British Journal of Educational Technology. 39(5): p. 787-806. https://doi.org/10.1111/j.1467-8535.2007.00773.x

Yeou, M., (2016), An investigation of students' acceptance of Moodle in a blended learning setting using technology acceptance model. Journal of Educational Technology Systems. 44(3): p. 300-318. http://dx.doi.org/10.1177/0047239515618464

Žuvić-Butorac, M., et al., (2011), Blended e-learning in higher education: Research on students' perspective. Issues in Informing Science and Information Technology. 8: p. 409. https://doi.org/10.28945/1427 